\title{
POTENTIAL OF PUBLIC AND PROFESSIONAL COMMUNICATIONS IN IMPLEMENTATION OF URBAN ENVIRONMENTAL PROGRAMS
}

\author{
IRINA TOPCHIY \& ALINA FATKULLINA \\ Moscow Institute of Architecture (State Academy), Russia
}

\begin{abstract}
This article is an independent study of Moscow residents' extent of awareness of the urban environmental programs. The aim of the study is to develop measures to support the urban ecology by schools of architecture. In 2019, the authors carried out a sociological survey with participation of several socially active groups: students of Moscow schools of architecture, participants of the Moscow Longevity Project and schoolchildren. The survey results showed that respondents are nearly unaware of the Environmental Doctrine of the Russian Federation, the UN Sustainable Development Goals and urban development programs. And, this is an impediment to implementation of environmental projects. Since the success and speed of implementation of environmental projects today to a greater extent depends on the combined actions of professionals: engineers, architects, economists, transport specialists, administrative workers and other persons who are 'line of duty' responsible for the quality of the urban life. And, support of residents who live, work and rest in the city space. The influence of residents on the final decision is really great, and they can be called 'non-professional players' of architectural and urban planning activities. Due to mismatching local and global interests, the desire to preserve the prevailing everyday habits and poor understanding of the long-term benefits from implementation of large-scale projects, residents' opinion concerning the prospects for urban development may not coincide with the opinion of professionals. And then conflicts arise. Environmental upbringing and education, covering all social groups of the urban population and including various types of activities, are today recognized as the most effective way to promote environmental projects. The survey proves that the respondents are well informed about the environmental problems of the city and unanimously believe that the responsibility for the implementation of the Projects lies with the city administration. They are ready to embrace an 'ecological lifestyle' if it brings economic benefits and does not disturb the customary lifestyle. It is concluded that in order to attract Moscow residents to implementation of environmental programs, it is necessary to be increasingly cognizant of the differences in the interests of social groups, replace economic pressure with economic benefits, and upscale an ecological lifestyle via media and public additional education.

Keywords: 'green framework of the city', social interaction in urban planning, strategies of urban development, supplementary and public architectural education, urban environment, 'urban softness'.
\end{abstract}

\section{INTRODUCTION}

\subsection{Purpose and objectives of research}

The purpose of this research was to study the specificities of public communications in the implementation of urban environmental projects in Moscow.

The research objectives included:

- review of international experience in involving urban residents in the implementation of urban environmental programs;

- highlighting the areas of environmental programs in Moscow, for the implementation of which residents' involvement is necessary; 
- holding a sociological survey among students of schools of architecture and socially active residents of Moscow, participants of the Moscow Projects 'University Saturdays' and 'Moscow Longevity' to specify their awareness of Moscow environmental Projects and Programs and their willingness to engage in their implementation.

\subsection{Methods of research}

Research methods include collection and study of written sources: scientific articles, publications in the media, dedicated to the participation of residents in the implementation of environmental projects in cities; review of urban projects and State environmental programs in terms of participation of residents in their implementation. Conducting an independent sociological study among representatives of various social groups in Moscow to specify the degree of their awareness and willingness to participate in urban environmental projects.

\section{STUDY OF INTERNATIONAL EXPERIENCE IN INVOLVING URBAN RESIDENTS IN THE IMPLEMENTATION OF URBAN ENVIRONMENTAL PROGRAMS}

The exponential growth in the number of scientific studies devoted to rational use, conservation of natural resources and the sustainable development of the human-made environment coincided with the beginning of the globalization period in the late 1980s. It became one of the global challenges the international community faced. In the succeeding decade, environmental programs were introduced into vocational education in most technical, humanities and social sciences. An environmental education strategy was defined by Tilbury (2008), Eckersley (1998), Huckle (2015), Rieckmann (2015) and others [1,2,3,4]. Various stages of students' perception of environmental threats were found (Hicks and Holden [5]). This resulted in a sense of empowerment of students. Hence, it was proved that all types of environmental education for the development of society in total is valuable.

Principal foreign universities and research centres that host interdisciplinary scientific conferences and engage new researchers in scientific work, ${ }^{1}$ currently support environmental and sustainable development topics. The European Commission ${ }^{2}$ regularly monitors the degree of environmental awareness of European Union residents and other countries of the world. The number of citizens who consider themselves well-informed on environmental issues in 2017 exceeded $97 \%$. Previous environmental awareness indicators ranged from $78 \%$ in Denmark to $30 \%$ in Romania [6]. The percentage of people who think that environmental protection is important for them personally ranges from country to country - from 87\% in Sweden to $40 \%$ in Cyprus and Croatia. There is a striking opinion discrepancy concerning which environmental problems should be tackled first. As most important the respondents consider the problems of climate change (up to 51\%), air pollution (46\%) and increasing waste generation (40\%).

Majority of environmental problems are caused by urbanization and, logically, fall within an area of interest of architects, urban planners, scientists and teachers of vocational schools.

Textbooks entered the practice of Russian-language architectural and urban planning vocational education in the 1990s. They covered the planning, organizational and technical aspects of ecology and sustainable urban development [7,8]. At present, the pedagogical studies of environmental education in our country and abroad are focused on formal types of education for schoolchildren and science and engineering students, forming a continuing education system. Methods and models for the organization of the human-made environment that take into account the sustainable development and uniqueness of urban ecosystems, the ecology 
of soils, forests, water and air, were proposed. The results of their research were introduced into the curricula of professional architecture education and were targeted at professional improvement of architects of all specialties. Long-term practice of environmental general and vocational education has contributed to a spread of environmental awareness among highly socially active and educated people.

To assess the capacity of public interaction in the implementation of urban environmental projects, it is necessary to study the experience of other countries and cities. Since the late 1970s, a project aimed at improving the ecology of the city and involving the city's residents in addressing environmental challenges, proposed by Jaime Lerner, the mayor of Curitiba (Brazil), has gained popularity. Curitiba's environmental problems during this period were typical for many cities in Latin America, Europe and Asia suffering from city budget deficit. Almost a quarter of a century later, in his book 'Acupuntura Urbana' (2003), Lerner analysed the results of his practical activities and demonstrated that a number of Curitiba's environmental challenges are characteristic for cities with an ample city budget, for example, Beijing (China), Rome (Italy), Seoul (South Korea), Mexico City (Mexico), and Strasburg (France). The author identified the key components of the structure of cities that hamper their development. And, he suggested solutions based on his experience. Each proposed measure, along with solving one of the environmental problems, took into account the financial interest of city residents and the prospective benefits.

The proposals made by Lerner were repeatedly cited in the works of other well-known theorists and practitioners of urban development. Thus, according to the unanimous opinion of American urbanists Kevin Lynch and Michael Larice, Brazilian Clovis Ultramari, Russian scientist V. Glazychev and others, to have the incentives for self-development, a city must have self-identity and feature mechanisms of society's influence on urban governance. Korean philosopher Young-Oak Kim in 2013 in The Great Equal Society [9] gave a philosophical underpinning for the importance of making managerial decisions and redeploying responsibility from the city administration to associations of various social urban groups.

Practical mechanisms of urban management, in the opinion of democratically minded scientists and urban planners, should be built on the principles of 'urban softness', which include supporting volunteer services and expanding the range of urban initiatives, developing national lifestyle, culture, art and private trade. Anything that facilitates creating new urban communities, unites various social groups of people, and addresses common goals is welcome. Social communities contribute to the emergence of integrated urban spaces that take into account the interests of different social groups, affecting their emotions and senses. A 30-year policy of 'urban softness', practiced in urban management in many European, North American and Latin American countries of the 21st century, resulted in townspeople perception of the city as a territory of public life, a place attractive for public initiatives and volunteering.

The policy of 'urban softness' was logically followed up by the new for the second half of the twentieth century ideas of public interaction and creation of new information flows within the city, which provided information about the urban environment, familiarized citizens with environmental issues and projects. In the absence of the Internet, it was important to overcome low awareness of the population. Besides publications in the media, information flows included construction of interactive educational and entertainment centres for young people; hanging banners, posters, information boards and other forms of visualization of city improvement projects. Today, the Internet takes over many, but not all, information functions.

Urban planning law in many countries worldwide includes the requirement to monitor public opinion on urban planning issues using sociological surveys, discussion of urban 
renewal projects and other forms of civil interaction. Openness and enhanced awareness about urban redevelopment projects and environmental projects help to improve trust to the city administration.

Participation of citizens in the approval of plans for reconstruction of the anthropogenic environment has long-term experience and the expertise has already been accumulated when a deliberately formed public opinion becomes a threat limiting territory development. The urban softness policy has its weak spots. Often, such a situation appears in locations where the interests of local communities and global interests collide.

Analysing the conflicts related to the reconstruction projects of the transport network, which were well-publicized and got covered in the state media, one can see that the public outcry was used by candidates for administrative posts in election campaigns [9, 10]. And it was manipulative and irrelevant to the real interests of cities and regions. It was suggested that as conflict-preventive measures new accountability mechanisms for both parties, which could hold both parties accountable [11], should be established. Public and educational organizations were encouraged to hold public discussions of projects, involving authors and professional experts, as well as to develop public educational programs.

The dialectical unity of the policy of 'urban softness' is based on the authoritarian form of urban management, which envisages strict observance of the rules established by the city authorities. From a political point of view, this form is not so popular, but it is equally effective and very common.

The creation of new urban areas on the man-made islands in Tokyo Bay can be cited as an example of the good urban environmental management through the establishment of legislative norms and regulations. The history of the man-made islands explains the choice of the authoritarian management policy. At the initial stage, the construction of artificial islands and collection of household waste were supported by the interests of the Japanese military in the 1970s, since at the height of the Cold War, artillery batteries were to be deployed on the islands. During the construction period, municipal and military governments developed methods for collecting and sorting garbage, which ensured a nonstop flow of raw materials for construction. In 2020, each of Tokyo's 23 districts has its own set of rules for sorting and purity degree of garbage, which are strictly followed. Cooperation of law enforcement agencies with the city administration accelerated the processes of changes of citizens' everyday habits. If in Curitiba, the collection of household waste was stimulated economically and was voluntary, then in Tokyo the change in the everyday behaviour of citizens was based on the law. Currently, the domestic waste management in Tokyo and a number of other Japanese cities is regulated by a tenancy agreement, occurs everywhere and is controlled by the municipal authorities. The stringency of Japanese laws on waste sorting and disposal is unexpected to foreigners.

The Japanese experience shows that the administrative and legal solutions to the domestic waste are as effective as finding economic mechanisms. The popularity of the artificial islands in Tokyo Bay is steadily increasing among residents and tourists. As evidenced by high real estate prices and an increase in the flow of tourists to Odaibo [12,13].

\section{ANALYSIS OF ENVIRONMENTAL PROGRAM DIRECTIONS IN LARGE CITIES IN WHICH RESIDENTS MAY BE INVOLVED}

Moscow's environmental problems are typical for many large Russian cities. The importance of the problem of household waste recycling in the Russian Federation is emphasized by the size of existing landfills. In 2019, their land area was estimated at 4 million ha. This is a little more than the territory of Luxembourg or a tenth of the area of Switzerland. For Russia, this 
is less than $0.00002 \%$. In general, the average population density in Russia is quite low. In 2020, it was 8.57 persons $/ \mathrm{km}^{2}$, while in the Benelux countries the population density is 380 per $1 \mathrm{~km}^{2}$. Comparing these figures, it would appear that it is easy to find new landfill sites. Thus, in 2019, an attempt was made to build a Shiyez landfill in the Arkhangelsk region for the disposal of Moscow waste. Although the distance from Moscow to the site is $1,153 \mathrm{~km}$, the authorities of Moscow and the Arkhangelsk region considered it beneficial. From the point of view of the authors of the project, the location was well chosen. There are no residential settlements in this area, but there is a railway access.

In the summer of 2020, the decision was cancelled as a result of residents' massive protests. Residents of the Russian North protested against administrative agreements between the two regions. The social activity of a landfills' 'denial' is minimally developed in 'positive' environmental actions. Let us use the example of Moscow for studying possible options of involving residents in the solution of urban ecology. The most commonly cited are transport problems, high levels of air pollution, a growing number of household waste dumps. According to statistics, only $4 \%$ of waste is further recycled. To improve this indicator, it is necessary to ensure the waste is sorted by residents. Improvement of the urban air quality directly depends on the degree of formation of the so-called 'green frame' of the city.

Moscow ranks among the most environmentally successful cities in Russia; its 'green frame' includes urban green spaces - forests, parks, public gardens, building surrounding grounds. They help to reduce noise and to purify groundwater. And, which is critical for a comfortable life, they provide good spatial rest environment for residents. That is, they are involved in a comprehensive solution of environmental issues. The peculiarity of the 'green frame' is that its life maintenance requires no less effort than creation.

If in cities and areas with intensive development, green planting management is funded from the city budget, then in cities with extensive development, it is necessary to establish civilian engagement mechanisms that help to involve residents in creating green spaces. In addition to the environmental and economic impact, this approach has long-term benefits and educational effects in recruiting young people for volunteer work.

It can be argued that in modern practice, volunteering is an effective mechanism to implement socially significant community projects, including environmental initiatives: landscaping and gardening of local areas, removing litter from coastlines, canals, parks and so on.

Another problem, which is relevant to cities of different sizes, from small ones to megalopolises and which is solved with city residents' participation, is to reduce air pollution from transport. Long ago, for Curitiba new high-speed transport schemes, which were later used in the reconstruction of Bogota (Colombia), Rio de Janeiro (Brazil), Shanghai (China) and some other cities, were proposed. Approaches to the organization of pick-up and drop-off zones were critically reflected, the organization of transport was considered together with waste management and organization of city residents' recreation. The important role of the city administration in coordinating the planned programs is obvious.

In accordance with the Environmental Doctrine of the Russian Federation and the UN Sustainable Development Goals, most of the urban development programs for 2019-2020 in Moscow are devoted to ecology. These include the program for the development of public passenger and freight transport: metro, public water, rail, road transport and optimization of traffic flows $[14,15]$. The comfortable constituent of using urban transport is based on the combined use of various modes of transport and the creation of an 'intelligent' transport network that provides combining various transport modes and its functioning as an integrated transport network. New transport means in Moscow are helicopter and bicycle transport, aimed at local transport needs and small flows. the municipal authorities are in charge 
of choosing territories for development of ground infrastructure as well as coordination of transport. Therefore, an urban program that supports the ecology of transport networks is the Information City program.

Most of the planned measures to improve the transport infrastructure and ecology of Moscow are settled by administrative measures, with mainly budget sourcing. Residents are encouraged to use bicycle instead of road transport for work-related travel and recreation. But we should not forget that due the climatic conditions of Moscow, bicycle transport can be used from May to November and for limited distances. On average, Muscovites, using the usual public transport (buses, trolleybuses and metro) travel between 1.5 and $2 \mathrm{~h}$ a day on the way from home to work. Changing to bicycles will increase the travel time by 1.5-2 times. Despite this, statistics show that in 2019, the number of people using rental bicycles increased by $17 \%$. And, the number of rides on rented bicycles reached almost 5 million. Considering that almost all rides occur in parks and on weekends, it is understandable that a bicycle in Moscow is more suitable for recreation, but not for daily work trips. For them, Muscovites continue to use public transport and private cars.

The UN Sustainable Development Goals carry several chapters aimed at reducing energy consumption. The Moscow State Energy Saving Program also contains organizational and managerial tasks that coordinate the division of responsibilities between various city departments. Focusing on the tasks to be carried out by the authorities together with residents, we highlight a reduction in the amount of consumed energy of all types and raising public awareness of energy conservation.

Another of Moscow's environmental programs, which is being tackled by the city authorities in cooperation with residents, is separate collection of household waste. It is being implemented from January 1, 2020 in Moscow. Thus far the role of the city government is to install containers of different colours for glass, paper, plastic and other waste instead of monochrome black waste containers. It is understood that residents will voluntarily and consciously sort out the waste and distribute it in containers of different colours. So far there are no requirements for the extent of waste disposal, for control of the correct sorting or for training in sorting techniques. Penalties for errors in waste sorting are not introduced yet.

Considering that today up to $88 \%$ of waste of the city with a population of 14 million is taken to landfills and this process has been going on for decades without changes, it is this issue that is singled out by the authors as the most important.

\section{SOCIOLOGICAL SURVEY OF MOSCOW RESIDENTS ABOUT THE EXTENT OF THEIR AWARENESS OF THE ENVIRONMENTAL PROGRAMS OF MOSCOW}

\subsection{Organization of sociological research}

A sociological research was carried out in September to November 2019 in the form of a survey. For developing the questionnaires, the UN Sustainable Development Goals (20152030), the Environmental Doctrines of the Russian Federation and the current state city programs of Moscow were used.

The reliability of the information collected was determined by the qualitative and quantitative selection of respondents - focus groups representing different age and professional categories of Muscovites and by a short survey period (September-November 2019). When selecting focus groups, the feasibility of application of the obtained data in professional and additional architectural education at the Moscow Architectural Institute (MARCHI) and Moscow State University of Civil Engineering (MGSU) was taken into account. Four focus 
Question 1. Awareness of the surveyed of international and national environmental projects. Professional participants in architecture and urban planning (students of architectural schools MARCHI and MGSU)

$\%$ of the total

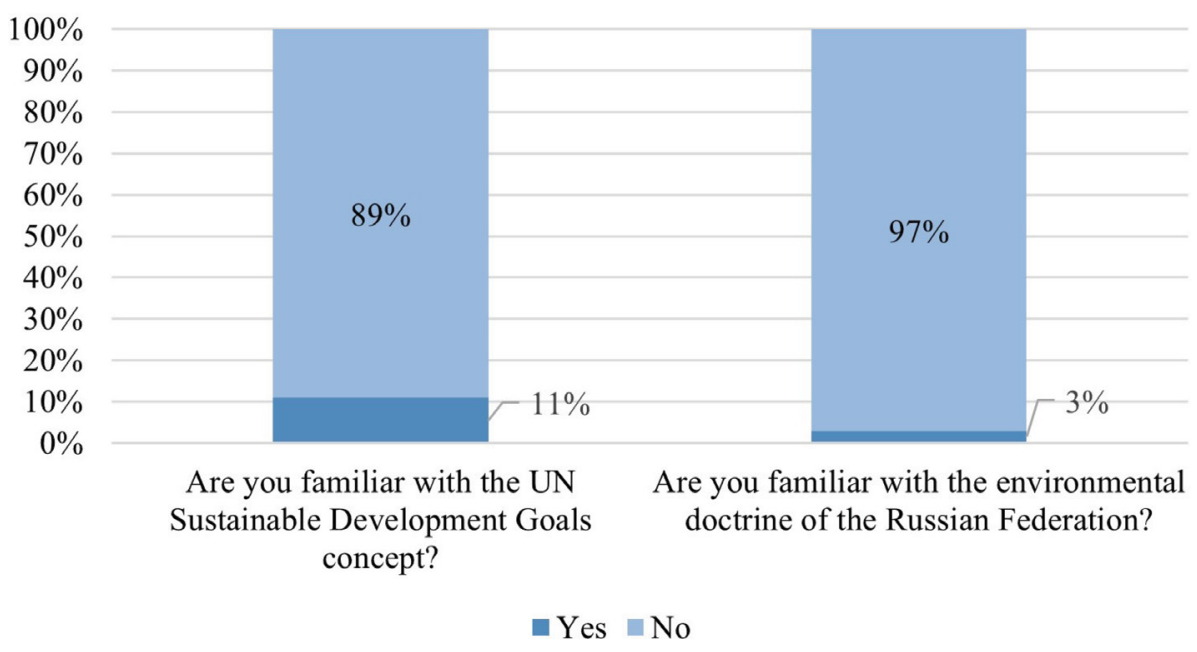

Question 1. Awareness of the surveyed of international and national environmental projects. Non-professional participants in architecture and urban planning (schoolchildren and their parents, pensioners) $\%$ of the total

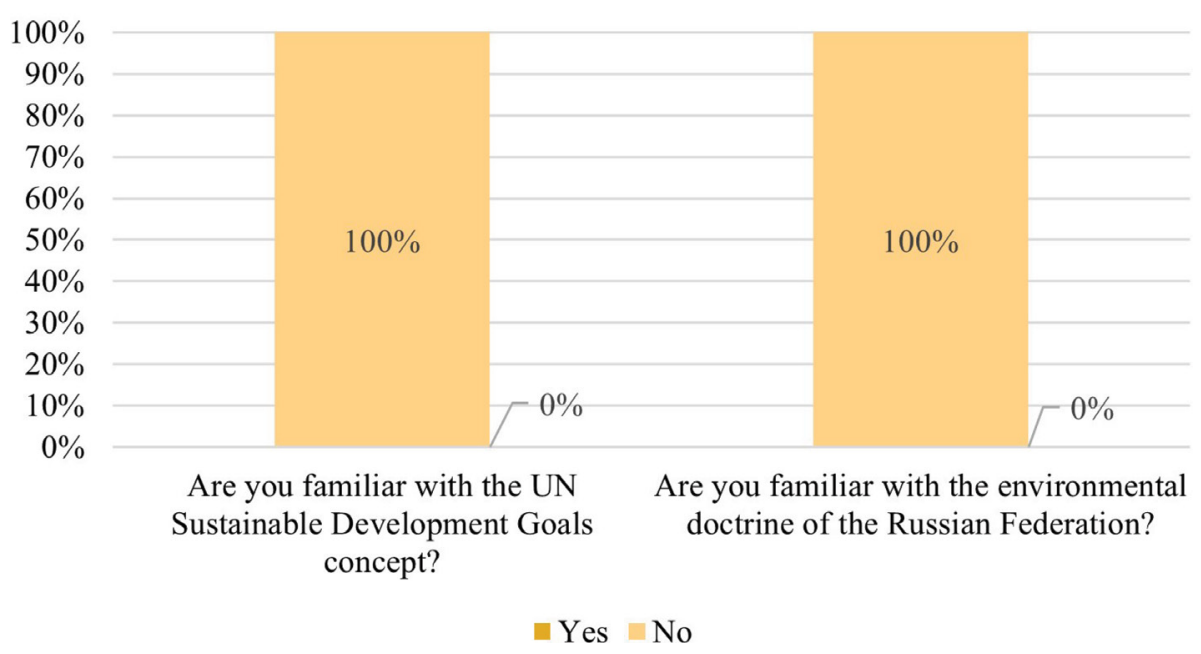

Figure 1: Answers to question 1. 
groups were identified: students of architectural faculties; students of pre-entry courses future applicants of architectural faculties; adults of different professions - parents of applicants; participants in the Moscow Longevity Project (women over 55 and men over 60). The survey was conducted either in openness or anonymity.

Two categories of respondents participated in the survey: those professionally involved in architecture and urban planning and city residents who evaluate and use the planning results, but are not involved professionally in architecture and urban planning activities however their participation is hailed for implementing environmental programs [16]. The number of persons in the groups is comparable to each other and is, respectively, 65 and 113 persons.

The share of residents under the age of 18 among Muscovites is $18 \%$, while people aged $60-69$ represent $12 \%$ of the residents. And, $11 \%$ of metropolitan population are people over 70. By bringing teenagers and senior residents in the study, we studied the opinion on the city's ecology of approximately $30 \%$ of Muscovites. The data variation rate is between $2 \%$ and $7 \%$, which indicates the uniformity of respondents' opinions.

\subsection{The content and results of the research}

The content of the research and its results are presented in Figures 1-5. Each table features a questionnaire and shows the percentage of respondents' answers as a percentage of the total (professional participants in architectural and urban planning - students of architectural schools and non-professional participants - schoolchildren and pensioners).

\section{RESEARCH RESULTS}

Representatives of all groups unanimously admitted that they are not familiar either with the Environmental Doctrine of the Russian Federation or with the UN Sustainable Development Goals. This fact indicates a lack of the related information support.

\section{Question 2. Level of awareness of the surveyed of the environmental problems of Moscow.}

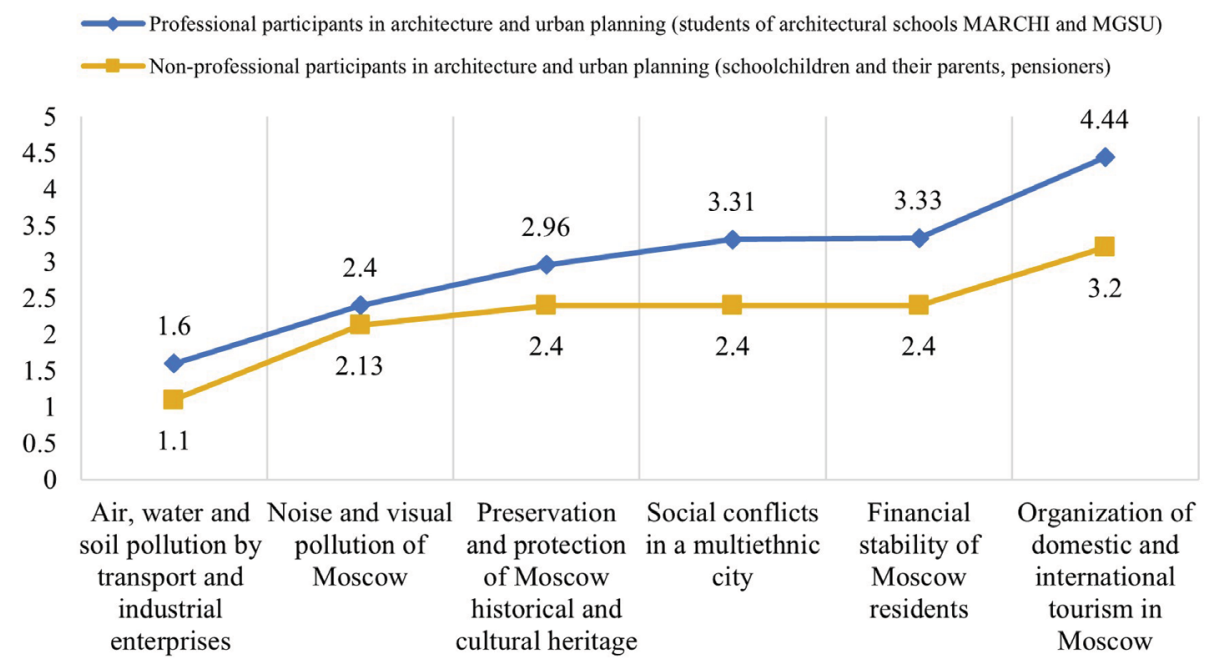

Figure 2: Answers to question 2. 
Question 3. Responsibility of residents for solving environmental problems of the city.

Non-professional participants in architecture and urban planning (schoolchildren and their parents, pensioners)

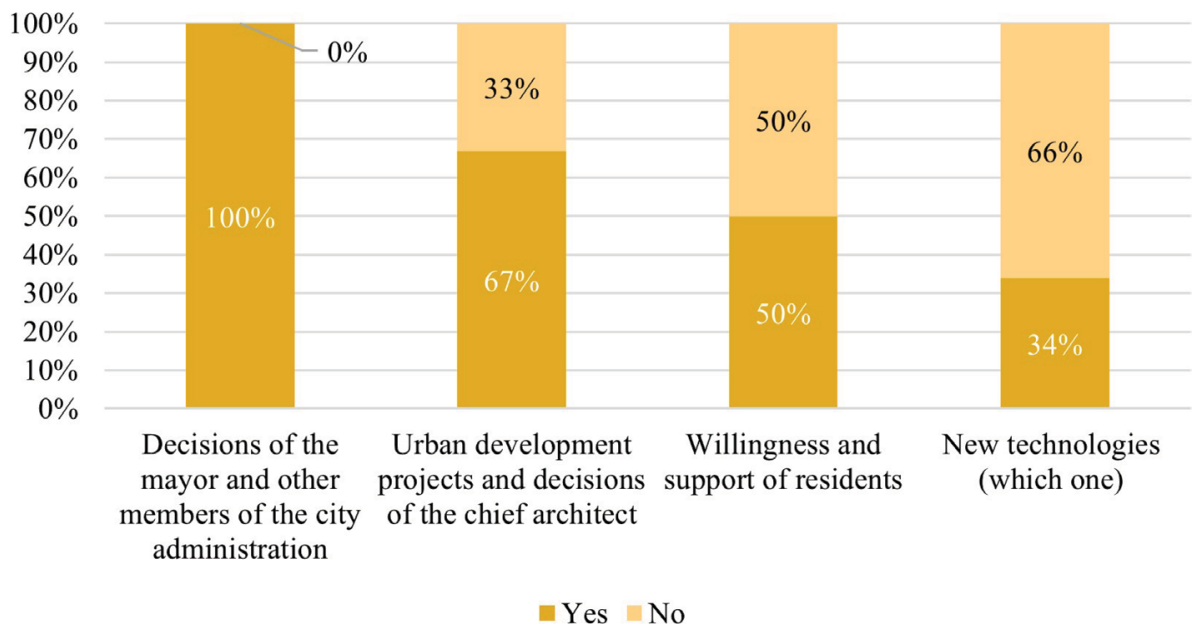

Question 3. Responsibility of residents for solving environmental problems of the city.

Professional participants in architecture and urban planning (students of architectural schools MARCHI and MGSU)

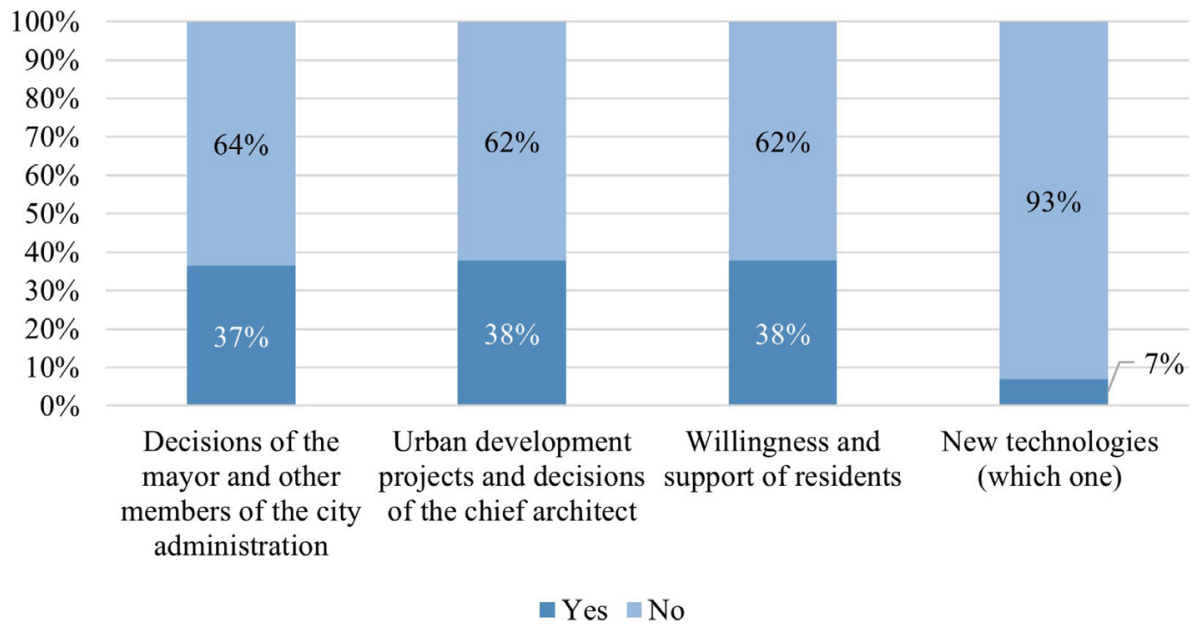

Figure 3: Answers to question 3. 
Question 4. Participation of Moscow residents in Environmental

Projects and movements. Professional participants in architecture and urban planning (students of architectural schools MARCHI and MGSU)

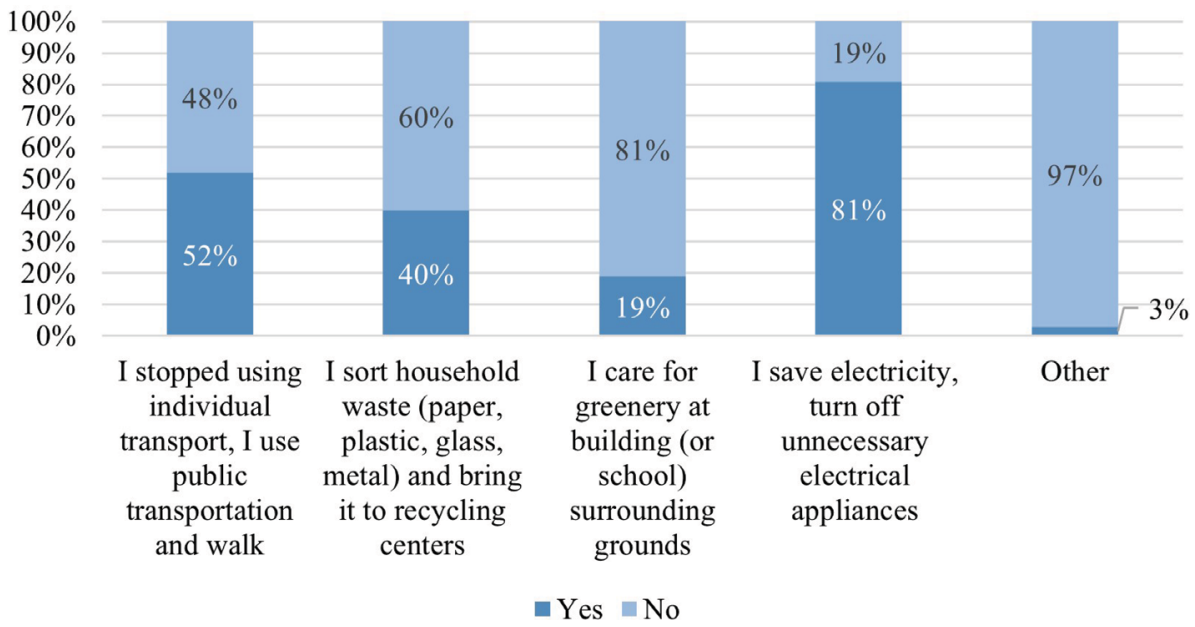

Question 4. Participation of Moscow residents in Environmental Projects and movements.

Non-professional participants in architecture and urban planning (schoolchildren and their parents, pensioners)

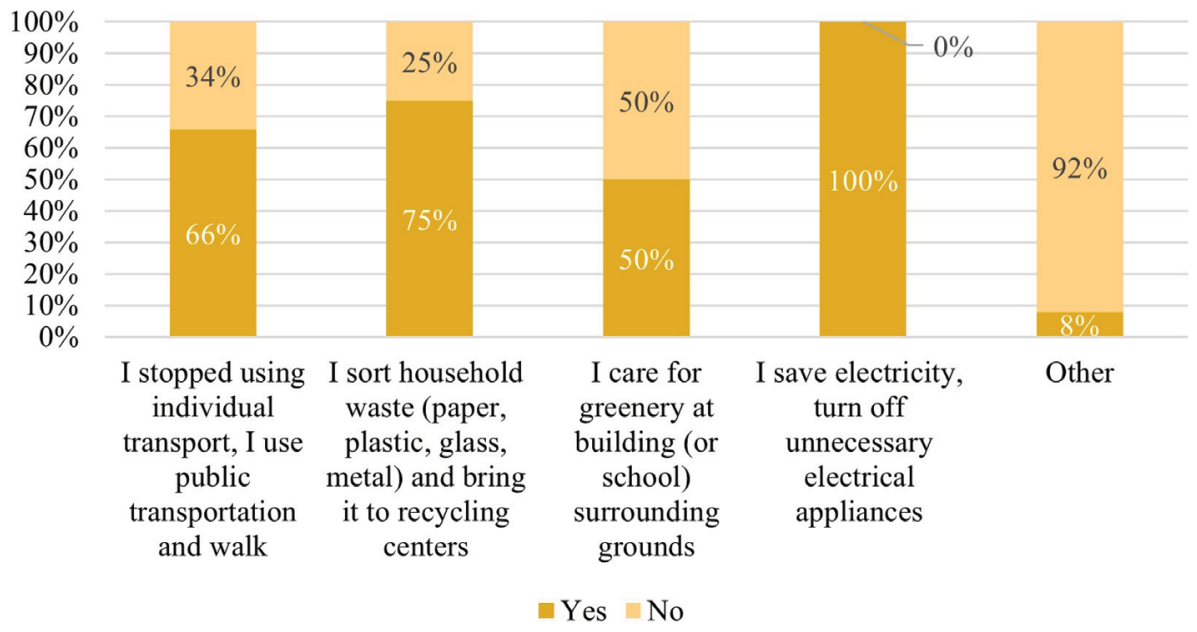

Figure 4: Answers to question 4. 
Question 5. Limitations and rejection of environmental initiatives.

Professional participants in architecture and urban planning (students of architectural schools MARCHI and MGSU)

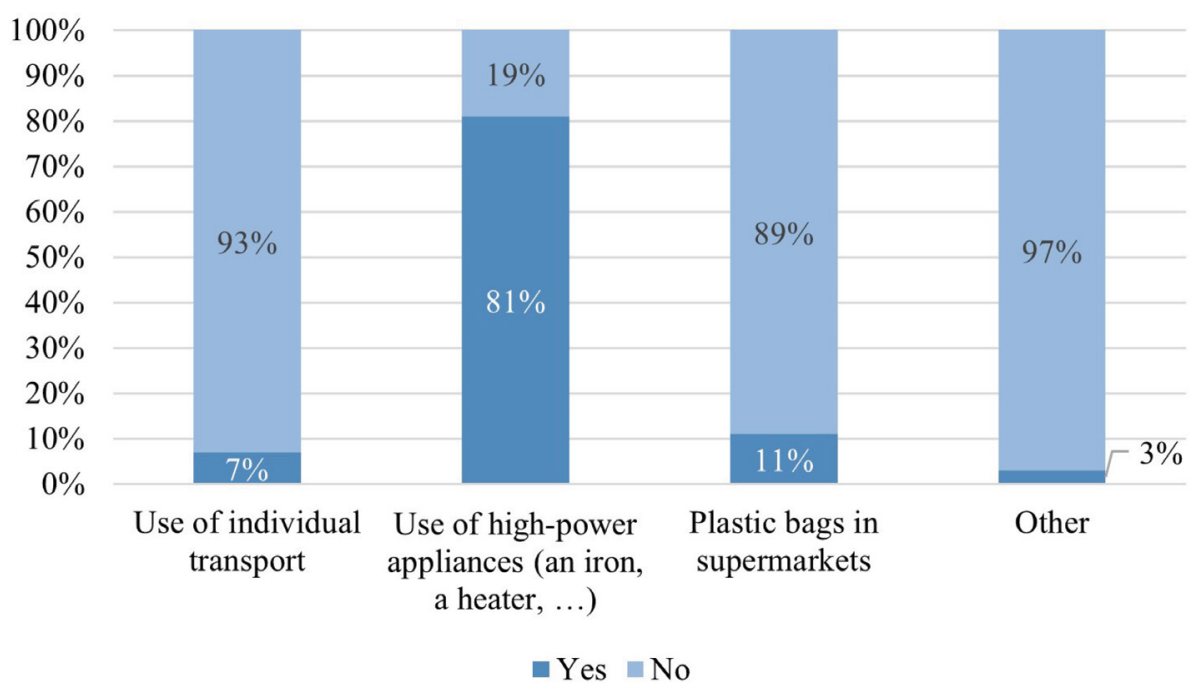

Question 5. Limitations and rejection of environmental initiatives. Non-professional participants in architecture and urban planning (schoolchildren and their parents, pensioners)

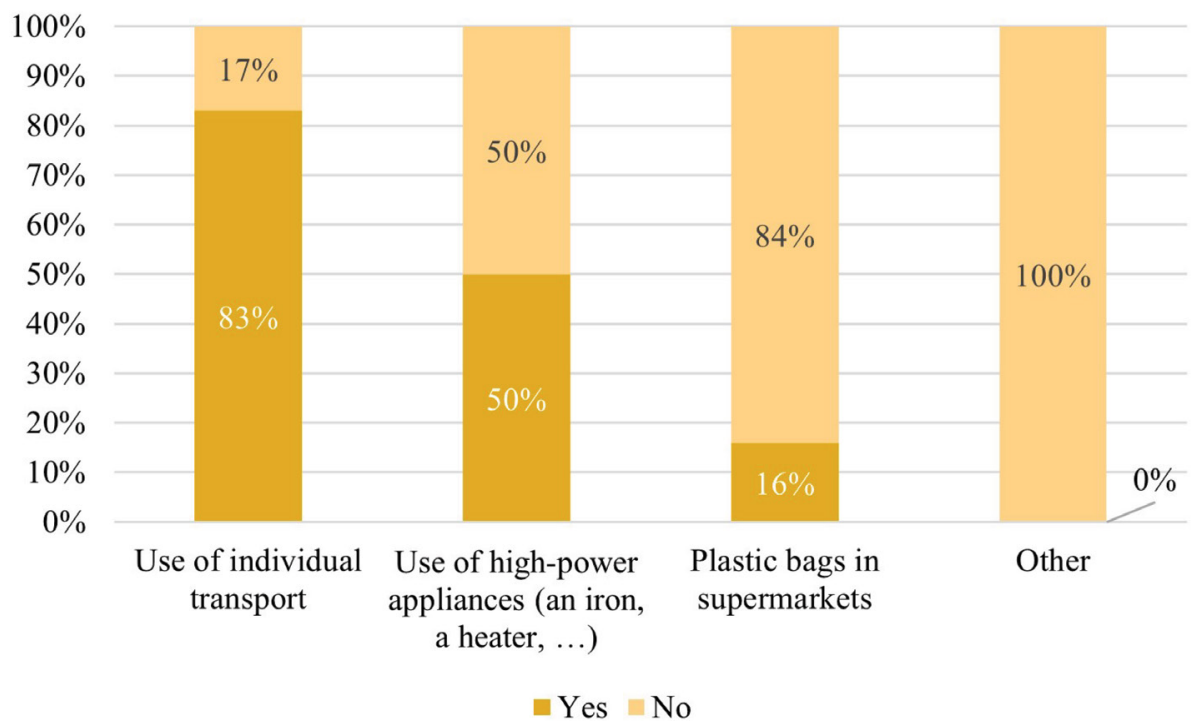

Figure 5: Answers to question 5. 
Respondents believe that all problems of sustainable development of the urban environment listed in the questionnaire are equally important. Younger respondents rated the transport problem a little higher than others. This is due to a higher mobility of the young generation and is confirmed by psychological and pedagogical researches that demonstrate that the growing commuting activity happens during professional growth and decreases with age.

Students and children are more interested in issues of organizing domestic and international tourism. At that all groups of respondents ranked the problem of ensuring the inflow of tourists as least important, despite the active media support of the federal target program 'Development of domestic and inbound tourism in the Russian Federation (2019-2025)' .

Respondents were unanimous in their opinion that the primary factor on which the sustainable development of the city depends is the activities of the Mayor of Moscow City and the city administration. The second in order of importance factor is 'urban development projects and decisions of the chief architect', the significance of which students of architectural schools consider as principal. The importance of 'willingness and support of residents' for sustainable development was noted by less than 5-7\% of the respondents of all social groups.

Answers to questions about participation in environmental movements and projects should be considered in strong dependence on the characteristics of social groups. The biggest number of positive responses $(50-80 \%)$ in the questionnaires filled in by children and older citizens refer to the 'I stopped using individual transport' item. Because these social categories are low in mobility and seldom use individual transport, their refusal to use it does not contradict usual patterns as well as a refusal to use high-power electric appliances which is both environmentally and economically efficient.

The idea of not using plastic bags offered in supermarkets was least supported by all social groups, which is surprising, considering that the plans for a phased reduction in the production of plastic bags, was already legally agreed upon with the Ministry of Natural Resources and Ecology of the Russian Federation.

\section{CONCLUSION}

The results of a sociological study of the awareness of Muscovites about global and national environmental projects and initiatives confirmed the hypothesis of a lack of awareness of the environmental problems of Moscow. but they also revealed Muscovites' understanding of the environmental problems of the city and their willingness to participate in their practical solutions. differences in the extent of participation and directions are associated with the characteristics of social groups, the degree of their mobility, ability to pay, availability of free time, and so on. taking into account residents' interests and abilities increases their concern in environmental programs.

According to the respondents the responsibility for the implementation of environmental projects in Moscow lies with the administrative structures of the city. Muscovites are not yet ready to change their everyday habits, especially in the use of personal transport, plastic containers and household refuse disposal. Muscovites are not ready to limit their consumption and sacrifice their usual level of comfort to reduce negative pressure on the environment. this approach prevents residents from being involved in environmental programs. overcoming this obstacle is a priority task, for the solution of which economic levers can be used, for example, reduction of penalties for waste disposal during sorting. and social impact methods such as social advertising and social action. bringing together educational institutions, catering establishments, public transport and other places of social intercommunication in practical actions for the separation of household waste will be instrumental for changing the habits 
of individuals. the logic of influencing individuals through communication points and social communities is determined by the normative nature of social actions of urban residents.

The participation of architectural professional educational institutions can be twofold: as part of organizations responsible for urban environmental programs on their territory. for instance, use of energy-saving technologies and separate waste collection at campuses and university buildings. and when creating their own programs of basic and additional education aimed at improving professional excellence of architects and the level of knowledge of the population in the field of urban ecology. in the first case, universities act as management entities, in the second - as action initiators.

\section{NOTES}

1. Wessex Institute, UK: The university of Exeter in Exeter, Devon and Falmouth, Cornwall, UK; Harvard University, USA; Norwegian Emergency Primary Healthcare Services, Norway; Japanese Center for International Studies in Ecology (IGES-JISE), Japan, etc.

2. Eurobarometer, EC web-site https://ec.europa.eu/COMMFrontOffice/publicopinion/ index.cfm.

3. Responses to the corresponding request in the Yandex.ru search engine amount to 15 million.

\section{REFERENCES}

[1] Tilbury, D. \& Wortman, D., How is community education contributing to sustainability in practice? Journal of Applied Environmental Education and Communication, 7(3), pp. 83-93, 2008.

[2] Eckersley, R., The death of nature and the birth of the ecological humanities. Organisation and Environment, pp. 183-185, 1998.

[3] Huckle, J., \& Sterling, S., Education for Sustainability. Earthscan: London, 1996.

[4] Rieckmann, M., Higher Education for Sustainable Development in Germany - Achievements, Good Practice and Next Practices. 2015.

[5] Hicks, D. \& Holden, C., Remembering the future: what do children think? Exploring the future: a missing dimension in environmental education. Environmental Education Research, 30, 2009.

[6] Punzo, G., Panarello, D., Pagliuca, M. \& Castellano, R., Evaluating the attitudes of Europeans towards the environment. Statistical Methods for Service Quality Evaluation. Cuzzolin.

[7] Titov E.V., Ecology, 7th ed. Academy: Moscow, 2019, 203p. ISBN: 5446884884 [in Russian].

[8] Ecology. Textbook for grades ten to eleven. ed. N.M. Chernova, 11th edition. Moscow, 2007, 304p. Moscow [in Russian].

[9] Topchiy, I.V., Architectural education as a method of preserving cultural heritage and preventing social conflicts. Architecture and Construction of Russia, 12. pp. 20-27, 2011 [in Russian].

[10] Young-Oak K., The Great Equal Society: Confucianism, China and the 21st Century, 1st edition, 2013. ISBN-13: 978-9814504713, ISBN-10: 9814504718.

[11] Lukacs, M., Who's defending Canada's national interest? First nations facing down a pipeline. The Guardian, 16 April 2018, https://www.theguardian.com/environment/ true-north/2018/apr/16/whos-defending-canadas-national-interest-first-nations-facingdown-a-pipeline. 
[12] Klaver, D.C., Roo, N., Good Governance of Land and Natural Resources: Balancing Local and Global Interests, January 2011 (seminar report).

[13] Horanont T., Phithakkitnukoon S., \& Shibasaki R., Sensing urban density using mobile phone GPS locations: a case study of Odaiba Area, Japan. Nature of Computation and Communication. ICTCC 2014. Lecture Notes of the Institute for Computer Sciences, Social Informatics and Telecommunications Engineering, vol 144. Vinh P., Vassev E., Hinchey M., eds. Springer: Cham. 2015. https://doi.org/10.1007/978-3-319-15392-6_15.

[14] Murayama M. \& Parker G., Suitable leisure and tourism space development in postindustrial cites: the case of Odaiba, Tokio, Japan. Tourism, Culture and Regeneration, pp. 69-83, 2006, CABI.

[15] Transport strategy of the Russian Federation for the period to 2030. Approved by the Federal Government on November 22, 2008 Order No. 1734, Moscow [in Russian].

[16] Decree of the Moscow city administration dated March 28, 2018. No. 138. On making changes to the Decree of Moscow city administration, September 27, 2011, 451 pp. On approval of the 'Development of municipal engineering infrastructure and energysaving technologies'. State program for Moscow [in Russian].

[17] Topchiy I.V., Subjects of architectural-urban activity. Architecture and Modern Information Technologies, 3(36) 2016, [in Russian]. 